\title{
Heat-resistivity and Local Structure of New Nuclear Waste Glass Composed of Calcium Aluminate and Lead Phosphate
}

\author{
Tetsuaki NiSHIDA ${ }^{\dagger}$, Keisuke MAKI and Motoshi SETO \\ Department of Chemistry, Faculty of Science, Kyushu University \\ Hakozaki, Higashi-ku, Fukuoka-shi 812-8581, Japan \\ Received December 24, 1998
}

\begin{abstract}
Aluminophosphate glass with a batch composition of $30 \mathrm{CaO} \cdot 15 \mathrm{Al}_{2} \mathrm{O}_{3} \cdot 5 \mathrm{Fe}_{2} \mathrm{O}_{3} \cdot 25 \mathrm{PbO} \cdot 25 \mathrm{P}_{2} \mathrm{O}_{5}$ was prepared as a potential host for the high-level nuclear wastes. This "base glass" consists of highly heat-resistant $60 \mathrm{CaO} \cdot(40-x) \mathrm{Al}_{2} \mathrm{O}_{3} \cdot x \mathrm{Fe}_{2} \mathrm{O}_{3}$ glass and water-resistant lead metaphosphate glass, $\mathrm{Pb}\left(\mathrm{PO}_{3}\right)_{2}$, which is known to have $\sim 10^{3}$ times higher water-resistivity than conventional borosilicate glass. Two crystallization temperatures $\left(T_{c}\right)$ of $650-671$ and $668-693{ }^{\circ} \mathrm{C}$ were determined from the differential thermal analysis (DTA) of the "base glass". Large activation energies of 4.2 and $4.9 \mathrm{eV}$ were obtained from a Kissinger plot of the $T_{c}$ values. Nuclear waste "model glass" containing 10 stable isotopes with the mass numbers of 90-100 ( $\mathrm{Sr}, \mathrm{Y}, \mathrm{Zr}, \mathrm{Nb}, \mathrm{Mo})$ and 135-145 (Ba, La, Ce, Pr, Nd) also shows high heat-resistivity. ${ }^{57} \mathrm{Fe}$ Mössbauer spectrum indicates that $\mathrm{Fe}$ (III) and $\mathrm{Fe}(\mathrm{II})$ are ionically bonded to distorted $\mathrm{PO}_{4}$ tetrahedra at the sites of network modifier.
\end{abstract}

Key Words: nuclear waste glass, calcium aluminate, lead phosphate, heat-resistivity, chemical durability, crystallization of glass, Mössbauer spectrum, differential thermal analysis, electron probe X-ray microanalyzer

\section{Introduction}

For the stable storage of high-level nuclear wastes for more than several thousands years, development of chemically and physically stable solid materials are required. Borosilicate glass, which is familiar to chemists, has been investigated for this purpose and several application studies have already been carried out. A great amount of radiation and heat emitted from the fission products of ${ }^{235} \mathrm{U}$ and transuranium elements are reported to destruct the host matrix for the nuclear wastes. It is considered that high heat-resistivity is a primary requisite to the actual nuclear waste hosts.

\footnotetext{
' Corresponding author：T. Nishida（西田哲明） Tel / Fax : (092) 642-2591, E-mail address : glassscc@mbox.nc.kyushu-u.ac.jp
}

Among several oxide glasses, aluminate glass has extremely high heat-resistivity ${ }^{1)-4)}$. Activation energies $\left(E_{\mathrm{a}}\right)$ of the crystallization of $60 \mathrm{CaO} \cdot 40$ $\mathrm{Al}_{2} \mathrm{O}_{3}, 60 \mathrm{CaO} \cdot 35 \mathrm{Al}_{2} \mathrm{O}_{3} \cdot 5 \mathrm{Fe}_{2} \mathrm{O}_{3}$ and $60 \mathrm{CaO} \cdot 27$ $\mathrm{Al}_{2} \mathrm{O}_{3} \cdot 13 \mathrm{Fe}_{2} \mathrm{O}_{3}$ glasses were determined to be $5.6-6.0,4.3-4.6$ and $4.2-4.9( \pm 0.3-0.4) \mathrm{eV}$, respectively ${ }^{1)} . E_{\mathrm{a}}$ values of $60 \mathrm{CaO} \cdot 10 \mathrm{BaO} \cdot 30$ $\mathrm{Al}_{2} \mathrm{O}_{3}, 60 \mathrm{CaO} \cdot 10 \mathrm{BaO} \cdot 17 \mathrm{Al}_{2} \mathrm{O}_{3} \cdot 13 \mathrm{Fe}_{2} \mathrm{O}_{3}$ and 60 $\mathrm{CaO} \cdot 10 \mathrm{BaO} \cdot 15 \mathrm{Al}_{2} \mathrm{O}_{3} \cdot 15 \mathrm{Fe}_{2} \mathrm{O}_{3}$ glasses were estimated to be $5.9,3.8$ and $3.9( \pm 0.3) \mathrm{eV}$, respectively $^{2)}$. It is noted that the $E_{\mathrm{a}}$ value of 60 $\mathrm{CaO} \cdot 10 \mathrm{BaO} \cdot 30 \mathrm{Al}_{2} \mathrm{O}_{3}$ glass $(5.9 \mathrm{eV})$ is equal to that of $60 \mathrm{CaO} \cdot 40 \mathrm{Al}_{2} \mathrm{O}_{3}$ glass $(5.6-6.0 \mathrm{eV})$. These values are equal to a sum of $\mathrm{Ca}-\mathrm{O}(1.4 \mathrm{eV})$ and $\mathrm{Al}-\mathrm{O}$ bond energies $(4.4 \mathrm{eV})$, suggesting that simultaneous cleavage of $\mathrm{Ca}-\mathrm{O}$ and $\mathrm{Al}-\mathrm{O}$ bonds triggers the crystallization. $60 \mathrm{CaO} \cdot 10 \mathrm{BaO} \cdot 17$ $\mathrm{Al}_{2} \mathrm{O}_{3} \cdot 13 \mathrm{Fe}_{2} \mathrm{O}_{3}$ and $60 \mathrm{CaO} \cdot 10 \mathrm{BaO} \cdot 15 \mathrm{Al}_{2} \mathrm{O}_{3} \cdot 15$ 
$\mathrm{Fe}_{2} \mathrm{O}_{3}$ glasses had smaller $E_{\mathrm{a}}$ values $(3.8-3.9 \mathrm{eV})$ than $60 \mathrm{CaO} \cdot 35 \mathrm{Al}_{2} \mathrm{O}_{3} \cdot 5 \mathrm{Fe}_{2} \mathrm{O}_{3}(4.3-4.6 \mathrm{eV})$ and $60 \mathrm{CaO} \cdot 27 \mathrm{Al}_{2} \mathrm{O}_{3} \cdot 13 \mathrm{Fe}_{2} \mathrm{O}_{3}$ glasses $(4.2-4.9 \mathrm{eV})$. These smaller $E_{\mathrm{a}}$ value will be associated with a marked decrease in the fraction of $\mathrm{Al}_{2} \mathrm{O}_{3}$ (15 or 17 mol\%), which is an effective heat-resistant material. The extensive replacement of $\mathrm{Al}_{2} \mathrm{O}_{3}$ by other metal (or non-metal) oxides will cause the degradation of the heat-resistivity. Recently, a marked decrease of $E_{\mathrm{a}}$ was observed in calcium gallate $\left(\mathrm{CaO}-\mathrm{Ga}_{2} \mathrm{O}_{3}\right)^{5)}$ and sodium tungstate $\left(\mathrm{Na}_{2} \mathrm{O}\right.$ $\left.\mathrm{WO}_{3}\right)^{6}$ glasses when a small amount $(1 \mathrm{~mol} \%)$ of $\mathrm{Ga}_{2} \mathrm{O}_{3}$ and $\mathrm{WO}_{3}$ was replaced by $\mathrm{Fe}_{2} \mathrm{O}_{3}$. It is noteworthy that aluminate glass shows high infrared (IR)-transparency, which may be utilized as IR-regulating glass, optical memory, etc. ${ }^{1)-4)}$. The high IR-transparency will be favorable for the nuclear waste glass, since the heat involved with the fission products and transuranium elements will be easily dispersed.

It is known that heat-resistivity of phosphate glass is much lower than that of borosilicate glass $^{4}$. Nevertheless, synthetic "phosphate" mineral termed "synrock", which has a similar composition to monazite, (Ce, Y, La, Th) $\mathrm{PO}_{4}$, has been developed as a high-level nuclear waste host $^{7), 8)}$. Sales and Boatner ${ }^{9)}$ reported that the corrosion-resistivity of lead phosphate glass, 50 $\mathrm{PbO} \cdot 50 \mathrm{P}_{2} \mathrm{O}_{5}$, in hot water $\left(90^{\circ} \mathrm{C}\right)$ was improved by a factor of $10^{5}$ by incorporating $9 \mathrm{wt} \%$ (extra weight) of $\mathrm{Fe}_{2} \mathrm{O}_{3}$ into the lead phosphate glass when prepared at $800-900^{\circ} \mathrm{C}$. Corrosionresistivity or chemical durability of the lead phosphate glass containing $9 \mathrm{wt} \%$ of $\mathrm{Fe}_{2} \mathrm{O}_{3}$ proved to be higher than that of borosilicate glass by a factor of $\sim 10^{3}$. This pioneering work by Sales and Boatner ${ }^{9)}$ shows that $\mathrm{Fe}(\mathrm{III})$ plays a significant role for the stable storage of nuclear wastes in lead phosphate glass. Introduction of alkalineearth metal or heavy metal oxide into phosphate glass seems to improve the corrosion-resistivity in hot water. High corrosion-resistivity and high mechanical strength of alkaline-earth phosphate glasses can be anticipated from the fact that glass and glass-ceramics of $\mathrm{CaO}-\mathrm{P}_{2} \mathrm{O}_{5}$, e.g., hydroxyapatite, are authorized as an excellent artificial bone joint, tooth root, etc. in the medical and dental fields.

This paper describes the characterization of aluminophosphate glass with a batch composition of $30 \mathrm{CaO} \cdot 15 \mathrm{Al}_{2} \mathrm{O}_{3} \cdot 5 \mathrm{Fe}_{2} \mathrm{O}_{3} \cdot 25 \mathrm{PbO} \cdot 25 \mathrm{P}_{2} \mathrm{O}_{5}$, which was prepared as a new host for the highlevel nuclear wastes. This "base glass" consists of highly heat-resistant calcium aluminate glass, 60 $\mathrm{CaO} \cdot 30 \mathrm{Al}_{2} \mathrm{O}_{3} \cdot 10 \mathrm{Fe}_{2} \mathrm{O}_{3}$, and water-resistant lead phosphate glass, $50 \mathrm{PbO} \cdot 50 \mathrm{P}_{2} \mathrm{O}_{5}$, i.e., lead metaphosphate : $\mathrm{Pb}\left(\mathrm{PO}_{3}\right)_{2}$. Heat-resistivity of the nuclear waste "base glass" was investigated by differential thermal analysis (DTA). $E_{\mathrm{a}}$ values of crystallization were determined with the Kissinger equation :

$$
\ln \left(T_{\mathrm{c}}{ }^{2} / \alpha\right)=E_{\mathrm{a}} / R T_{\mathrm{c}}+\text { const., }
$$

in which $T_{\mathrm{c}}, \alpha$ and $R$ are the crystallization peak temperature (in $\mathbf{K}$ ), heating rate in DTA and the gas constant, respectively. ${ }^{57} \mathrm{Fe}-\mathrm{Mössbauer}$ spectroscopy was applied for evaluating the local structural role of iron in the nuclear waste "base glass". DTA and Mössbauer techniques were also applied to the nuclear waste "model glass" containing 10 stable isotopes with the mass numbers of 90-100 (Sr, Y, Zr, Nb, Mo) and 135-145 $(\mathrm{Ba}, \mathrm{La}, \mathrm{Ce}, \mathrm{Pr}, \mathrm{Nd})$. These stable isotopes were incorporated into the "base glass" as the simulated fission products of ${ }^{235} \mathrm{U}$.

\section{Experimental}

\subsection{Preparation of glass}

Nuclear waste "base glass", $30 \mathrm{CaO} \cdot 15 \mathrm{Al}_{2} \mathrm{O}_{3} \cdot 5$ $\mathrm{Fe}_{2} \mathrm{O}_{3} \cdot 25 \mathrm{PbO} \cdot 25 \mathrm{P}_{2} \mathrm{O}_{5}$, was prepared by melting the mixture of $\mathrm{CaCO}_{3}, \mathrm{Al}(\mathrm{OH})_{3}, \mathrm{Fe}_{2} \mathrm{O}_{3}, \mathrm{PbO}$ and 
$\mathrm{P}_{2} \mathrm{O}_{5}$ of guaranteed reagent grade at $1400^{\circ} \mathrm{C}$ for 3 $\mathrm{h}$ in an electric muffle furnace. This melting temperature is lower than that for $60 \mathrm{CaO} \cdot(40-x)$ $\mathrm{Al}_{2} \mathrm{O}_{3} \cdot x \mathrm{Fe}_{2} \mathrm{O}_{3}$ glasses, i.e., $1550^{\circ} \mathrm{C}^{1)-4)}$, due to the presence of less heat-resistant $50 \mathrm{PbO} \cdot 50 \mathrm{P}_{2} \mathrm{O}_{5}$ in the mixture. After the fusion, the melt in a platinum crucible was quenched with ice-cold water and homogeneous "base glass" of dark brown (which looked almost black) was prepared. A simulated nuclear waste "model glass" was prepared by melting small pieces of the "base glass" with the powdered reagent mixture (oxide or carbonate) of 11 stable isotopes ( $\mathrm{Sr}, \mathrm{Y}, \mathrm{Zr}, \mathrm{Nb}, \mathrm{Mo}$, $\mathrm{Cs}, \mathrm{Ba}, \mathrm{La}, \mathrm{Ce}, \mathrm{Pr}, \mathrm{Nd})$ at $1350^{\circ} \mathrm{C}$ for $2 \mathrm{~h}$. The simulated nuclear waste is composed of equal numbers of individual atoms, and the weight ratio of the "base glass" to the simulated wastes (reagent mixture) was fixed to $9: 1$. Technetium (Tc) and xenon (Xe) were excluded from the reagent mixture since the former has no stable isotope and the latter is "gas" at the room temperature.

\section{$2 \cdot 2$ Characterization of glass}

Crystallization peak temperatures $\left(T_{\mathrm{c}}\right)$ and activation energies $\left(E_{\mathrm{a}}\right)$ were determined by DTA conducted at heating rates $(\alpha)$ of $5,10,15$ and 20 $\mathrm{K}$ min ${ }^{-1}$, using powdered $\alpha-\mathrm{Al}_{2} \mathrm{O}_{3}$ as the standard. Mössbauer spectra were observed by the constant acceleration method with a ${ }^{57} \mathrm{Co}(\mathrm{Pd})$ source and a reference of $\alpha$-Fe foil, which was also used for the velocity calibration (abscissa of the spectrum). Since the samples contain a large amount of $\mathrm{Pb}$ and other heavy metals, Mössbauer spectra were measured after diluting the glass powder with powdered boron nitride (BN). Elemental analysis of these samples was performed with the electron probe X-ray microanalyzer (EPMA).

\section{Results and Discussion}

The EPMA study revealed that the "base glass" had a composition of $40 \mathrm{CaO} \cdot 11 \mathrm{Al}_{2} \mathrm{O}_{3} \cdot 6 \mathrm{Fe}_{2} \mathrm{O}_{3}$. $14 \mathrm{PbO} \cdot 29 \mathrm{P}_{2} \mathrm{O}_{5}$, instead of the batch composition of $30 \mathrm{CaO} \cdot 15 \mathrm{Al}_{2} \mathrm{O}_{3} \cdot 5 \mathrm{Fe}_{2} \mathrm{O}_{3} \cdot 25 \mathrm{PbO} \cdot 25 \mathrm{P}_{2} \mathrm{O}_{5}$. Increases of the relative fraction of $\mathrm{CaO}, \mathrm{Fe}_{2} \mathrm{O}_{3}$ and $\mathrm{P}_{2} \mathrm{O}_{5}$ were observed together with a slight decrease of $\mathrm{Al}_{2} \mathrm{O}_{3}$ from 15 (batch composition) to $11 \mathrm{~mol} \%$ ("base glass"). A backscattering electron image (BEI) of the scanning electron microscope revealed the presence of a small amount (a few \%) of crystalline particles with a composition of $93 \mathrm{Al}_{2} \mathrm{O}_{3} \cdot 6.7 \mathrm{Fe}_{2} \mathrm{O}_{3} \cdot 0.3 \mathrm{PbO}$. These crystalline particles, which precipitated during the sample preparation, seem to have reduced the relative fraction of $\mathrm{Al}_{2} \mathrm{O}_{3}$ in the "base glass". The marked decrease of $\mathrm{PbO}$ from $25 \mathrm{~mol} \%$ in the reagent mixture (batch composition) to $14 \mathrm{~mol} \%$ in the "base glass" will be due to the evaporation during the sample preparation at $1350-1400^{\circ} \mathrm{C}$. The EPMA study revealed the absence of cesium (Cs), although it was originally included in the reagent mixture when the nuclear waste "model glass" was prepared. It is known that $\mathrm{Cs}, \mathrm{Na}$ and Mo are volatile in borosilicate glass system ${ }^{10)}$. All other elements in the reagent mixture, i.e., Sr, $\mathrm{Y}$, $\mathrm{Zr}, \mathrm{Nb}, \mathrm{Mo}, \mathrm{Ba}, \mathrm{La}, \mathrm{Ce}, \mathrm{Pr}, \mathrm{Nd}$, were preserved in the "model glass", except for a slight weight loss of Mo.

DTA curves of the "base glass" show two exothermic peaks at the crystallization temperatures $\left(T_{\mathrm{c}}\right)$ of $650-671^{\circ} \mathrm{C}$ and $668-693^{\circ} \mathrm{C}$ (Figs. 1 (a)(d), depending on the heating rates of $5-20 \mathrm{~K}$ $\min ^{-1}$. DTA curves of the "model glass", containing 10 stable isotopes, showed only one exothermic peak at the $T_{\mathrm{c}}$ of $696-724^{\circ} \mathrm{C}$ (Figs. 1 (e)(h)) when heated at the rates of $5-20 \mathrm{~K} \mathrm{~min}^{-1}$. Figures $1(\mathrm{e})-(\mathrm{h})$ indicate that the incorporation of 10 elements ( $\mathrm{Sr}, \mathrm{Y}, \mathrm{Zr}, \mathrm{Nb}, \mathrm{Mo}, \mathrm{Ba}, \mathrm{La}, \mathrm{Ce}, \mathrm{Pr}$, 

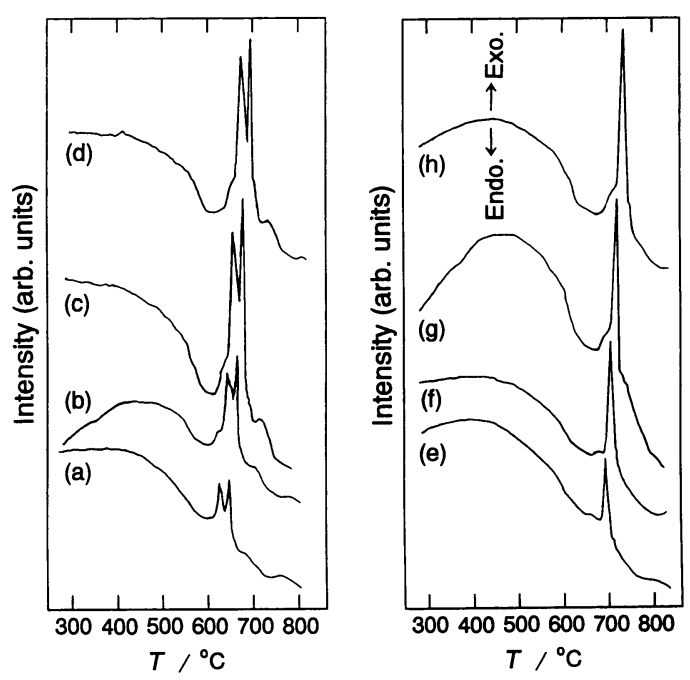

Fig. 1 DTA curves of the nuclear waste "base glass" recorded at heating rates of (a) 5 , (b) 10 , (c) 15 and (d) 20 $\mathrm{K} \mathrm{min}^{-1}$, and those of the nuclear waste "model glass" recorded at heating rates of (e) 5 , (f) 10 , (g) 15 and (h) $20 \mathrm{~K} \mathrm{~min}^{-1}$.

$\mathrm{Nd)}$ into the "base glass" brings about an improved heat-resistivity by about $30-50^{\circ} \mathrm{C}$. It is noted that the $T_{\mathrm{c}}$ values of the "base glass" (650671 and $668-693^{\circ} \mathrm{C}$ ) and the "model glass" (696$724{ }^{\circ} \mathrm{C}$ ) are much lower than those of binary 60 $\mathrm{CaO} \cdot 40 \mathrm{Al}_{2} \mathrm{O}_{3}$ glass $\left(926-955^{\circ} \mathrm{C}\right)^{1,3)}$ or $60 \mathrm{CaO} \cdot$ $27 \mathrm{Al}_{2} \mathrm{O}_{3} \cdot 13 \mathrm{Fe}_{2} \mathrm{O}_{3}$ glass $\left(769-814^{\circ} \mathrm{C}\right)^{1)}$, due to the coexistent $\mathrm{PbO}$ and $\mathrm{P}_{2} \mathrm{O}_{5}$. This result suggests that $T_{\mathrm{c}}$, softening temperature and even the melting temperature can be regulated by changing the relative fraction of calcium aluminate and lead phosphate. It is noteworthy that "ancient glass" is observed nowadays as it was, in spite that it is essentially alkali silicate glass having lower heatresistivity and lower corrosion-resistivity than aluminophosphate glass. Therefore, it is expected that we can prepare new nuclear waste glass in which radioactive wastes are stably stored for more than several thousands years.

Activation energy $\left(E_{\mathrm{a}}\right)$ of crystallization be-

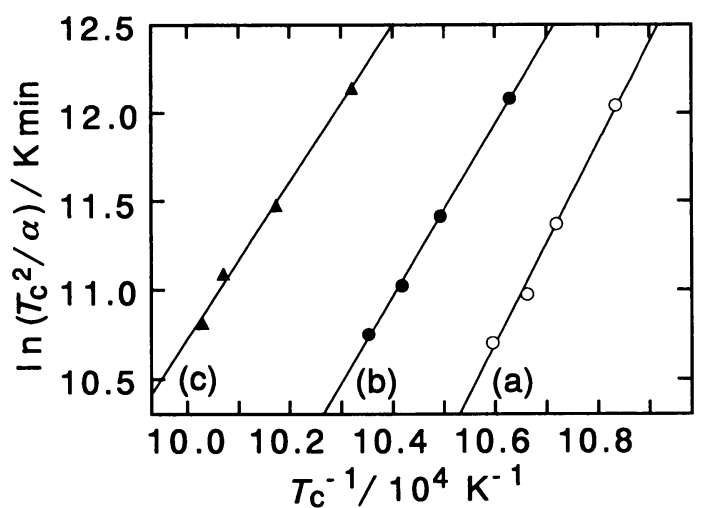

Fig. 2 Kissinger plots for the crystallization peak temperatures $\left(T_{\mathrm{c}}\right)$ of (a) $650-671^{\circ} \mathrm{C}$ and (b) $668-693^{\circ} \mathrm{C}$ obtained from the DTA curves of the nuclear waste "base glass" (see Figs. 1 (a)-(d)). A Kissinger plot for the $T_{\mathrm{c}}$ values of the nuclear waste "model glass", $696-724^{\circ} \mathrm{C}$ (see Figs. 1 (e)-(h)), is illu-strated in (c).

comes an important key when determining the heat-resistivity and the stability of glass. Kissinger plots for the "base glass" and "model glass" are illustrated in Fig. 2. All the plots show straight lines with similar slopes, which yield $E_{\mathrm{a}}$ values of 4.9 (Fig. 2 (a)), 4.2 (Fig. 2 (b)) and $3.8 \mathrm{eV}$ (Fig. 2 (c)). Almost comparable $E_{\mathrm{a}}$ values were recently obtained for $60 \mathrm{CaO} \cdot 35 \mathrm{Al}_{2} \mathrm{O}_{3} \cdot 5 \mathrm{Fe}_{2} \mathrm{O}_{3}$ (4.3$4.6 \mathrm{eV})^{1)}, 60 \mathrm{CaO} \cdot 27 \mathrm{Al}_{2} \mathrm{O}_{3} \cdot 13 \mathrm{Fe}_{2} \mathrm{O}_{3}(4.2-4.9 \mathrm{eV})^{1)}$, $60 \mathrm{CaO} \cdot 10 \mathrm{BaO} \cdot 17 \mathrm{Al}_{2} \mathrm{O}_{3} \cdot 13 \mathrm{Fe}_{2} \mathrm{O}_{3}(3.8 \mathrm{eV})^{2)}$ and $60 \mathrm{CaO} \cdot 10 \mathrm{BaO} \cdot 15 \mathrm{Al}_{2} \mathrm{O}_{3} \cdot 15 \mathrm{Fe}_{2} \mathrm{O}_{3}$ glasses (3.9 $\mathrm{eV})$. The $E_{\mathrm{a}}$ values of $3.8-4.9 \mathrm{eV}$ obtained in the present study indicate that both the "base glass" and "model glass" behave as a heat-resistant aluminate glass. These $E_{\mathrm{a}}$ values suggest that the avage of $\mathrm{Al}-\mathrm{O}$ bond having a single bond energy of ca. $4.4 \mathrm{eV}^{11)}$ or the simultaneous cleavage of $\mathrm{Ca}-\mathrm{O}$ and $\mathrm{Fe}-\mathrm{O}$ bonds triggers the crystallization, as recently observed in aluminate and gallate glasses containing iron ${ }^{1), 2), 5)}$.

Mössbauer spectra of the "base glass" and 


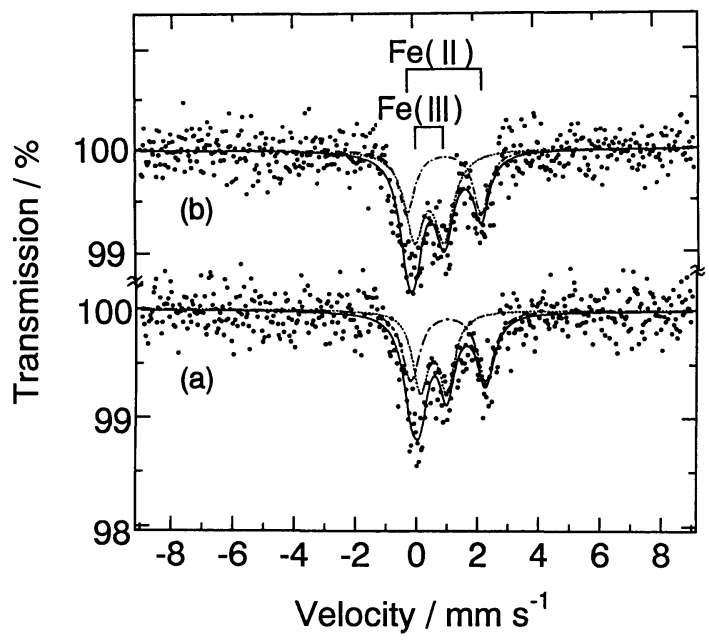

Fig. 3 Mössbauer spectra of the nuclear waste (a) "base glass" and (b) "model glass" measured at room temperature.

"model glass" are shown in Figs. 3 (a) and (b), respectively. All the Mössbauer parameters are summarized in Table 1. Although the absorption intensity was not high due to the shielding effect of the $\gamma$-rays $(E=14.4 \mathrm{keV})$ by the coexistent lead $(\mathrm{Pb})$, Mössbauer spectra evidently showed the absorption peaks due to $\mathrm{Fe}$ (III) and $\mathrm{Fe}$ (II). Large isomer shift values $(\delta)$ of 0.53 ("base glass") and 0.52 ( \pm 0.01$) \mathrm{mm} \mathrm{s}^{-1}$ ("model glass") indicate that $\mathrm{Fe}$ (III) ions are ionically bonded to several distorted $\mathrm{PO}_{4}$ tetrahedra at the sites of network modifier (NWM), as are often observed in several phosphate glasses ${ }^{4)}$. The com- parable $\delta$ values of 0.52 and $0.53 \mathrm{~mm} \mathrm{~s}^{-1}$ indicate that $\mathrm{Fe}$ (III) ions have essentially the same $\mathrm{Fe}-\mathrm{O}$ bond length and chemical bond strength, irrespective of the presence of about $10 \mathrm{wt} \%$ stable isotopes. The same $\delta$ values of $1.02( \pm 0.01) \mathrm{mm} \mathrm{s}^{-1}$ obtained for $\mathrm{Fe}$ (II) ions in the "base glass" and "model glass" indicate that they are surrounded by several $\mathrm{PO}_{4}$ units at NWM sites.

Quadrupole splitting value $(\Delta)$ of $\mathrm{Fe}(\mathrm{III})$ increased from $0.86 \pm 0.02 \mathrm{~mm} \mathrm{~s}^{-1}$ in the "base glass" to $0.99 \pm 0.02 \mathrm{~mm} \mathrm{~s}^{-1}$ in the "model glass" as a result of the dissolution of 10 stable isotopes. This result means a marked increase in the distortion, i.e., a marked decrease in the local symmetry at the $\mathrm{Fe}$ (III) sites. At the same time, the linewidth values $(\Gamma)$ for the $\mathrm{Fe}($ III) increased from 0.61 ("base glass") to $0.75( \pm 0.02) \mathrm{mm} \mathrm{s}^{-1}$ ("model glass"), reflecting widely distributed $\mathrm{Fe}-$ $\mathrm{O}$ bond lengths and $\mathrm{O}-\mathrm{Fe}-\mathrm{O}$ angles. By contrast, $\Delta\left(2.45\right.$ and $\left.2.49 \mathrm{~mm} \mathrm{~s}^{-1}\right)$ and $\Gamma(0.68$ and 0.63 $\mathrm{mm} \mathrm{s}^{-1}$ ) values of $\mathrm{Fe}(\mathrm{II})$ in the "base glass" and “model glass" were almost the same as each other, within the experimental error of $\pm 0.02 \mathrm{~mm} \mathrm{~s}^{-1}$. These results indicate that $\mathrm{Fe}$ (II) is less sensitive to the local structural change than Fe(III), probably because the chemical (ionic) bond of the former is weaker than that of the latter. (Ionic bond strength of metal ion is proportional to the $z / r$ value, in which $z$ and $r$ are the charge and ionic radius, respectively.)

Table 1 Mössbauer parameters for the nuclear waste "base glass" and "model glass"

\begin{tabular}{llcccc}
\hline Sample & Species & $\begin{array}{c}\delta^{\mathrm{a})} \\
\left(\mathrm{mm} \mathrm{s}^{-1}\right)\end{array}$ & $\begin{array}{c}\Delta^{\mathrm{b})} \\
\left(\mathrm{mm} \mathrm{s}^{-1}\right)\end{array}$ & $\begin{array}{c}\Gamma^{\mathrm{c})} \\
\left(\mathrm{mm} \mathrm{s}^{-1}\right)\end{array}$ & $\begin{array}{c}A^{\mathrm{d})} \\
(\%)\end{array}$ \\
\hline Base glass & $\mathrm{Fe}(\mathrm{III})$ & 0.53 & 0.86 & 0.61 & 48.8 \\
Model glass & $\mathrm{Fe}(\mathrm{II})$ & 1.02 & 2.45 & 0.68 & 51.2 \\
& $\mathrm{Fe}(\mathrm{III})$ & 0.52 & 0.99 & 0.75 & 60.8 \\
& $\mathrm{Fe}($ II $)$ & 1.02 & 2.49 & 0.63 & 39.2 \\
\hline
\end{tabular}

a) Isomer shift w.r.t. $\alpha$-Fe. b) Quadrupole splitting. c) Linewidth (FWHM).

d) Relative absorption area. 
It is generally known that metal ions of higher oxidation state is preferentially observed in several oxide glasses when melted at lower temperatures. Table 1 shows that the relative absorption area $(A)$ of $\mathrm{Fe}(\mathrm{III})$ in the Mössbauer spectrum is $48.8 \pm 0.5 \%$ in the "base glass", while it is $60.8 \pm$ $0.5 \%$ in the "model glass". This will be due to the difference in the melting temperature at which the sample was prepared, i.e., $1400^{\circ} \mathrm{C}$ for the "base glass" and $1350^{\circ} \mathrm{C}$ for the "model glass". Table 1 indicates that a part of $\mathrm{Fe}$ (II) ions in the "base glass" was oxidized to $\mathrm{Fe}(\mathrm{III})$ in the "model glass" when melted at $1350^{\circ} \mathrm{C}$. Phosphorus pentoxide $\left(\mathrm{P}_{2} \mathrm{O}_{5}\right)$ in oxide glasses plays a role of reducing agent for metal ions ${ }^{4}$. Introduction of about $10 \mathrm{wt} \%$ stable elements in the simulated nuclear waste will not be responsible for the oxidation of $\mathrm{Fe}$ (II) to $\mathrm{Fe}$ (III), since simulated nuclear waste was extraneously added to the "base glass" and hence the $\mathrm{Fe}$ (III) $/ \mathrm{P}_{2} \mathrm{O}_{5}$ ratio in the "model glass" is the same as that in the "base glass". We can conclude from the Mössbauer spectra that the iron in the "model glass" has essentially the same chemical and structural environment as that in the "base glass", except that the former is more distorted than the latter, owing to the simulated nuclear waste. Several metal ions in the simulated nuclear waste will occupy the sites of NWM, as do the $\mathrm{Fe}$ (III) and $\mathrm{Fe}(\mathrm{II})$, being ionically bonded to distorted $\mathrm{PO}_{4}$ tetrahedra. This conclusion is consistent with the high heat-resistivity of the "model glass" that was confirmed from the DTA study.

\section{Summary}

(1) A new nuclear waste "base glass" could be prepared from highly heat-resistant $60 \mathrm{CaO} \cdot(40$ $-x) \mathrm{Al}_{2} \mathrm{O}_{3} \cdot x \mathrm{Fe}_{2} \mathrm{O}_{3}$ glass and water-resistant lead metaphosphate glass, $\mathrm{Pb}\left(\mathrm{PO}_{3}\right)_{2}$.

(2) The "base glass" has high crystallization peak temperatures $\left(T_{\mathrm{c}}\right)$ of $650-671$ and $668-$ $693^{\circ} \mathrm{C}$, of which Kissinger plot yields large activation energies $\left(E_{\mathrm{a}}\right)$ of 4.9 and $4.2 \mathrm{eV}$, respectively.

(3) A nuclear waste "model glass" containing 10 stable isotopes $(\mathrm{Sr}, \mathrm{Y}, \mathrm{Zr}, \mathrm{Nb}, \mathrm{Mo}, \mathrm{Ba}, \mathrm{La}, \mathrm{Ce}$, $\mathrm{Pr}, \mathrm{Nd})$ shows high heat-resistivity with large $T_{\mathrm{c}}$ and $E_{\mathrm{a}}$ values of $696-724^{\circ} \mathrm{C}$ and $3.8 \mathrm{eV}$, respectively.

(4) Both $\mathrm{Fe}$ (III) and $\mathrm{Fe}$ (II) preferentially occupy the sites of network modifier (NWM) and are ionically bonded to distorted $\mathrm{PO}_{4}$ tetrahedra.

(5) Several metal ions in the nuclear wastes will occupy the sites of NWM, as do the Fe(III) and $\mathrm{Fe}(\mathrm{II})$.

(6) DTA and Mössbauer spectroscopy proved to be useful tools for evaluating the heatresistivity and local structure of the nuclear waste glass.

\section{Acknowledgments}

The authors are grateful to Dr. Masakatsu Saeki, Japan Atomic Energy Research Institute (Nuclear Technology and Education Center), for his guidance, comments and discussion. They are also indebted to Mr. Kazuhiko Shimada, Kyushu University (Department of Earth and Planetary Science) for the kind help in the operation of EPMA. Kyushu Environmental Evaluation Association (President : Yoshimasa Takashima, Prof. Emer., Kyushu University) financially supported this paper.

\section{References}

1) Nishida, T., Kubuki, S., Shibata, M., Maeda, Y. and Tamaki, T.: J. Mater. Chem., 7, 1801-1806 (1997)

2) Kubuki, S. and Nishida, T.: J. Radioanal. Nucl. Chem., 239, (2), 303-307 (1999)

3) Nishida, T. and Kubuki, S. : ibid., 239, (2), 237240 (1999)

4) Nishida, T.: "Mössbauer Spectroscopy of Sophis- 
ticated Oxides" (Vértes, A. and Homonnay, Z., eds), pp. 27-87 (ch. 2), Akadémiai Kiadó, Budapest (1997)

5) Kubuki, S., Nishida, T., Kaung, P., Yagi, T. and Maeda, Y.: J. Non-Cryst. Solids, 209, 87-95 (1997)

6) Nishida, T., Suzuki, M., Kubuki, S., Katada, M. and Maeda, Y.: ibid., 194, 23-33 (1996)

7) Ringwood, A. E., Kesson, S. E., Ware, N. G., Hibberson, W. and Major, A.: Nature, 278, 219223 (1979)
8) Ryerson, F. J.: J. Am. Ceram. Soc., 67, (2), 75-82 (1984)

9) Sales, B. C. and Boatner, L. A.: Science, 226, 4548 (1984)

10) Strachan, D. M., Barnes, B. O. and Turcotte, R. P.: "Scientific Basis for Nuclear Management" (Moore, J. G., ed.), Vol. 3, pp. 347-354, Plenum, New York (1981)

11) Chakravorty, D.: "Modern Aspects of Solid State Chemistry", pp. 391-423, Plenum, New York (1980)

要 旨

\title{
アルミン酸カルシウムとリン酸鉛により構筑される新しい放射性廃棄物 ガラスの耐熱性と局所構造
}

\author{
西田哲明，真木啓介，瀬戸基司 \\ 九州大学理学部化学教室 \\ 812-8581 福岡市東区箱崎 6-10-1
}

\begin{abstract}
放射性廃棄物ガラスとして, 熱に強い $60 \mathrm{CaO} \cdot(40-x) \mathrm{Al}_{2} \mathrm{O}_{3} \cdot x \mathrm{Fe}_{2} \mathrm{O}_{3}$ ガラスと, 而水性に優れた $\mathrm{Pb}\left(\mathrm{PO}_{3}\right)_{2}$ ガラスから成るアルミノリン酸塩ガラスを調製した。示差熱分析 (DTA) から求めた結 晶化ピーク温度のキッシンジャープロットから, 結晶化の活性化エネルギー $\left(E_{\mathrm{a}}\right)$ が 4.2 および $4.9 \mathrm{eV}$ であり, 而熱性に優れた材料であることを実証した。質量数が 90 - 100 ( $\mathrm{Sr}, \mathrm{Y}, \mathrm{Zr}, \mathrm{Nb}, \mathrm{Mo}$ ) および 135 - 145 (Ba, La， Ce, Pr, Nd) の安定核種を溶融した放射性廃棄物モデルガラスについて

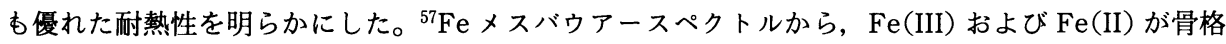
の隙間で網目修飾イオン $(\mathrm{NWM})$ として存在し， $\mathrm{PO}_{4}$ 四面体とイオン結合をしていることを明ら かにした。
\end{abstract}

